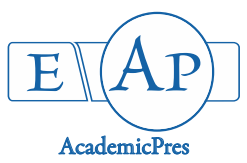

Brearley FQ (2021)

Notulae Scientia Biologicae

Volume 13, Issue 2, Article number 10976

DOI: $10.15835 / \mathrm{nsb} 13210976$

Short Original Article

\title{
Nutrient and metal concentrations in Nepenthes macfarlanei Hemsl. (Nepenthaceae) from a Malaysian montane forest
}

\author{
Francis Q. BREARLEY
}

\author{
Manchester Metropolitan University, Department of Natural Sciences, Chester Street, \\ Manchester, M1 5GD,UK;.f.brearley@mmu.ac.uk
}

\begin{abstract}
Palaeotropical pitcher plants (Nepenthes) are a fascinating evolutionary case but their nutrient relationships are poorly known. To determine nutrient and metal concentrations in Nepenthes macfarlanei from Peninsular Malaysia, and contribute to our understanding of nutrient relationships in this genus, plants were sampled from the Genting Highlands - a disturbed montane forest location. Whilst many foliar nutrients showed typical concentrations, the foliar $\mathrm{N}$ concentration was, surprisingly, greater than most lowland species although the N:P ratio (c. 24) indicated nitrogen limitation in line with other studies on Nepenthes. Of particular note was the variable but high $\left(<240 \mu \mathrm{g} \mathrm{g}^{-1}\right)$ lead concentrations that have not been reported in carnivorous plants before. This data adds to our understanding of the nutrient relationships of carnivorous plants and shows that they may accumulate high concentrations of certain metals.
\end{abstract}

Keywords: carnivorous plants; lead; nutrient limitation; plant-soil relationships; pollution

\section{Introduction}

The montane forests of Peninsular Malaysia are a rich source of plant diversity (Saw, 2010). One example is the Genting Highlands, well-studied due to its proximity to the capital city Kuala Lumpur (Piggot, 1977; Stone, 1981; Chua and Saw, 2001; Bedawi et al., 2009; Ng et al., 2012). Whilst much of the area has been converted to buildings to service the tourist industry, there are still fragments of disturbed and natural vegetation. Of the 14 species of Nepenthes found in Peninsular Malaysia (McPherson and Robinson, 2012; Ghazalli et al., 2020; Tamizi et al., 2020), three species, viz. Nepenthes macfarlanei Hemsl., Nepenthes ramispina Ridl. and Nepenthes sanguinea Lindl. (along with natural hybrids between them) are found here (Shivas, 1983; Chua and Saw, 2001; Bourke, 2003). These pitcher plants present a fascinating case of plant evolution whereby they have developed a container ('pitcher') at the end of their leaf blades to catch insects and other nutritious materials to supplement their soil-derived nutrients (Thorogood et al., 2018). Through examination of nutrient concentrations and nutrient ratios, it appears this genus of pitcher plants are nitrogen limited (Brearley and Mansur, 2012; Mansur et al., in revision). However, there is little data from montane Nepenthes species to further support this suggestion. Additionally, there is little data on metal concentrations in Nepenthes species (but see van der Ent et al., 2015) and the current development in this area may lead us to use this genus for biomonitoring of pollution in the future. The objective of this study was to determine

Received: 11 May 2021. Received in revised form: 07 Jun 2021. Accepted: 09 Jun 2021. Published online: 23 Jun 2021.

From Volume 13, Issue 1, 2021, Notulae Scientia Biologicae journal uses article numbers in place of the traditional method of continuous pagination through the volume. The journal will continue to appear quarterly, as before, with four annual numbers. 
nutrient and metal concentrations in Nepenthes macfarlanei and contribute to our understanding of nutrient relationships in this genus.

\section{Materials and Methods}

\section{Description of the study site}

The Genting Highlands are found at $3^{\circ} 26^{\prime} \mathrm{N}, 101^{\circ} 47 \mathrm{E}$ in Peninsular Malaysia on the Selangor-Pahang border at around $1750 \mathrm{~m}$ a.s.l. and based on a granitic geology (Whitmore and Burnham, 1969). Tropical montane forest is the dominant vegetation found in the area although around the summit has been heavily disturbed by roads and high-rise buildings for the development of the well-known tourist resort.

\section{Sampling design}

Three plants of Nepenthes macfarlanei (Figure 1) were sampled from around the summit of Gunung Ulu Kali (the Telecom Tower) in February 2011. A single leaf (all leaves were estimated to be less than one year old) was collected from each plant, dried in a forced air oven and stored dry until analysis.

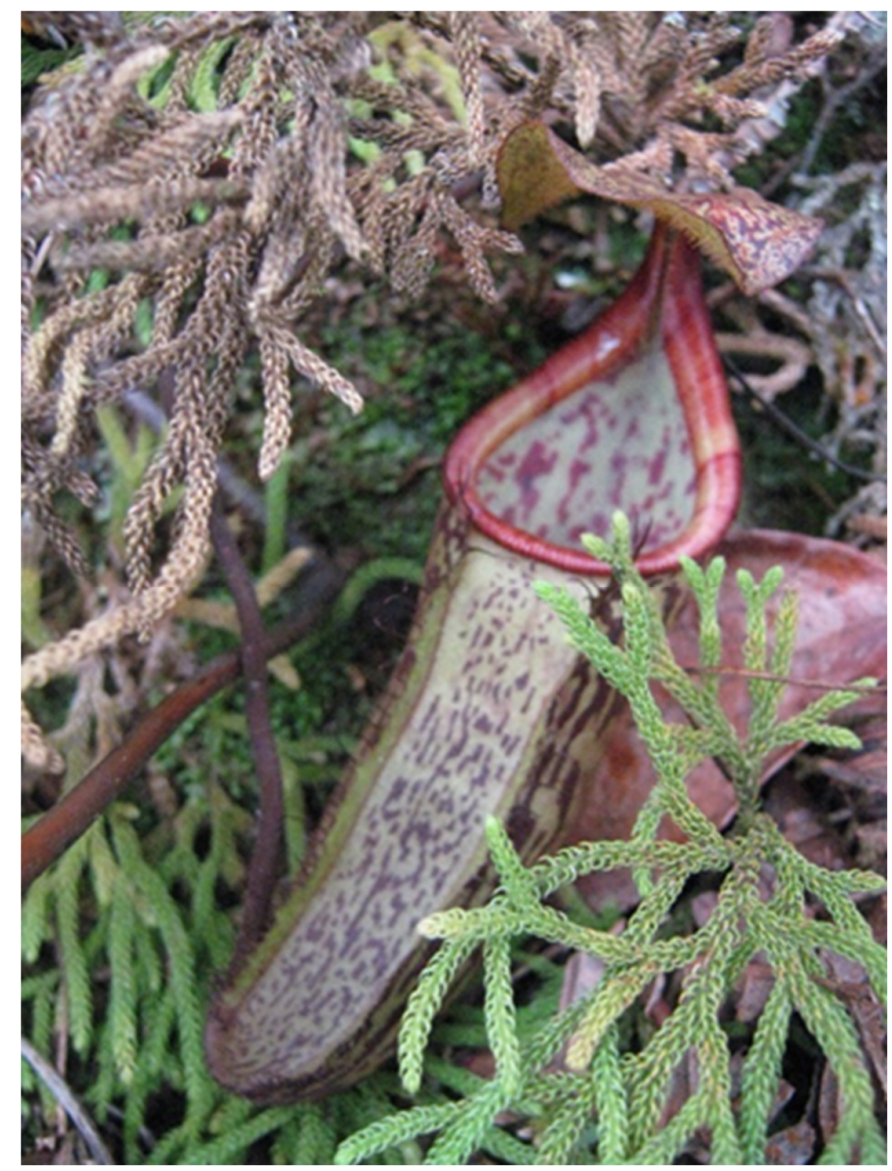

Figure 1. Nepenthes macfarlanei at the Genting Highlands, Malaysia

\section{Experimental procedures}

About $650 \mathrm{mg}$ of leaf material was digested in $2.5 \mathrm{ml}$ concentrated sulphuric acid with a lithium sulphate/selenium (100:1) catalyst at $375^{\circ} \mathrm{C}$ for 4 hours, diluted with deionized water, and analysed for 
nutrient concentrations on a Dionex ICS-5000 Ion Chromatography System (for N) or a Thermo iCAP 6300 Duo Inductively Coupled Plasma Optical Emission Spectrometer (for all other elements).

\section{Results and Discussion}

The results for the macronutrients showed typical concentrations (Figure 2) although nitrogen was high when compared with other studies (Osunkoya et al., 2007; Brearley and Mansur, 2012), which is surprising given that nitrogen availability generally decreases with elevation in tropical regions (Tanner et al., 1998). High nitrogen concentrations at this location could be due to localised deposition from traffic and other sources. However, the other macronutrients fell within the range for other Nepenthes species from Borneo (Osunkoya et al., 2007; Brearley and Mansur, 2012; van der Ent et al., 2015; Mansur et al., in revision). The nitrogen-tophosphorus ratio was around 24 suggestive of nitrogen limitation (using the criteria of Ellison, 2006) although was wider than other studies from lowland (Osunkoya et al., 2007; Brearley and Mansur, 2012) or submontane (Mansur et al., in revision) elevations - this was due to the high nitrogen rather than low phosphorus. There is very little data on micronutrients in Nepenthes species but, again, our data (Table 1) were all within the range for typical 'healthy' plants (Pugnaire, 2001) across a range of habitats and were similar to previous studies from peat swamp forest (Brearley and Mansur, 2012) but were lower than concentrations from plants growing in ultramafic soils where greater foliar nickel, chromium and cobalt were shown (van der Ent et al., 2015). Granitic soils do not present high concentrations of these metals, but the acidic montane soils can increase the availability to plants of many metals. However, Nepenthes seems to exclude these metals to a certain extent, possibly due to their small root systems that limits nutrient uptake (van der Ent et al., 2015). Metal concentrations within the Nepethens macfarlanei plants were variable and, interestingly, lead was much higher than other studies with c. $240 \mathrm{\mu g} \mathrm{g}^{-1}$ as a maximum concentration which is particularly high and could be due to the density of traffic at this location. Highly variable concentrations of these micronutrients suggest that uptake via roots may not be the main pathway of uptake and direct deposition via leaf surfaces or via the pitchers may be more important (Rotkittikhun et al., 2006). The high lead concentration from this study site contrasts markedly with a site in central Borneo where lead was below detection limits in the majority of samples but there was a single plant of Nepenthes albomarginata with $19.6 \mu \mathrm{g} \mathrm{g}^{-1}$ foliar lead (Brearley, unpubl. data). Adlassnig et al. (2009) have shown that pitcher plants other than Nepenthes take up the metallic elements iron and manganese, so the uptake from insects highly enriched in such metals could be another possibility but would need additional data on elemental concentration in insects to test this.

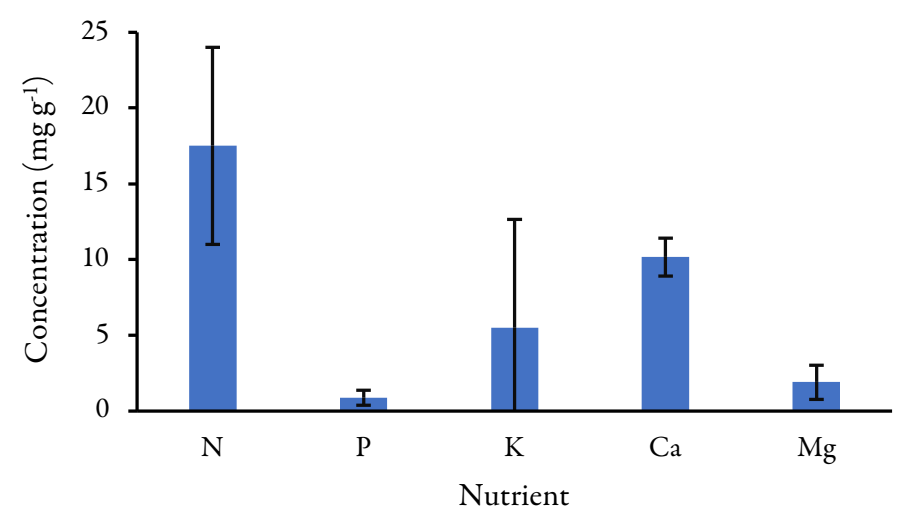

Figure 2. Macronutrient concentrations (mean \pm standard deviation) in Nepenthes macfarlanei at the Genting Highlands, Malaysia 
Table 1. Metal concentrations (mean \pm standard deviation) in Nepenthes macfarlanei at the Genting Highlands, Malaysia; metals are ordered by their concentration in the leaf tissue

\begin{tabular}{|c|c|}
\hline Metal & Concentration $\left(\mu \mathrm{g} \mathrm{g}^{-1}\right)$ \\
\hline $\mathrm{Mn}$ & $240 \pm 139$ \\
\hline $\mathrm{Al}$ & $98.0 \pm 85.0$ \\
\hline $\mathrm{Pb}$ & $80.6 \pm 139.7$ \\
\hline $\mathrm{Zn}$ & $60.3 \pm 68.5$ \\
\hline $\mathrm{Cu}$ & $4.94 \pm 5.35$ \\
\hline $\mathrm{Ni}$ & $1.84 \pm 0.65$ \\
\hline $\mathrm{As}$ & $1.78 \pm 1.11$ \\
\hline $\mathrm{Co}$ & $0.10 \pm 0.18$ \\
\hline
\end{tabular}

Although there is considerable amount of protected forest in the Genting Highlands, Nepenthes species are threatened by informal plant collection as well as for construction activities. However, there is increased interest in Nepenthes conservation in the area (e.g. The Star, 2016) so we hope for positive conservation outcomes for this genus into the future.

\section{Conclusions}

This paper adds another data point to our understanding of Nepenthes pitcher plant nutrient relationships and further suggests primary nitrogen limitation of this genus whilst noting additional micronutrient composition of the plants and the potential to take up metallic elements to unexpectedly high concentrations.

\section{Authors' Contributions}

Conceptualization (FQB); Data curation (FQB); Formal analysis (FQB); Investigation (FQB); Methodology (FQB); Project administration (FQB); Resources (FQB); Validation (FQB); Visualization $(\mathrm{FQB}) ;$ Writing - original draft $(\mathrm{FQB}) ;$ Writing - review and editing (FQB). The author read and approved the final manuscript.

\section{Acknowledgements}

I thank Martin Cheek (Kew) for assistance with identification, David McKendry (MMU) for assistance with nutrient analyses and Lee Su See (Forest Research Institute of Malaysia) for hospitality. This research received no specific grant from any funding agency in the public, commercial, or not-for-profit sectors.

\section{Conflict of Interests}

The author declares that there are no conflicts of interest related to this article. 


\section{References}

Adlassnig W, Steinhauser G, Peroutk M, Musilek A, Sterba JH, Lichtscheidl IK, Bichlerb M (2009). Expanding the menu for carnivorous plants: uptake of potassium, iron and manganese by carnivorous pitcher plants. Applied Radiation and Isotopes 67(12):2117-2122. https://doi.org/10.1016/j.apradiso.2009.04.006

Bedawi, SHA, Go R, Mustafa M (2009). New records of terrestrial pteridophytes in Genting Highlands, Pahang, Malaysia. Pertanika Journal of Tropical Agricultural Science 32(2):169-174. http://www.pertanika.upm.edu.my/resources/files/Pertanika\%20PAPERS/JTAS\%20Vol.\%2032\%20(2)\%20 Aug.\%202009/12\%20Pages\%20169-174.pdf

Bourke G (2003). Exploring the Genting Highlands. Carniflora Australis 2:14-16 and 23-26. http://auscps.tech2u.net/wp-content/uploads/carniflora-oct-2003.pdf

Brearley FQ, Mansur M (2012). Nutrient stoichiometry of Nepenthes species from a Bornean peat swamp forest. $\begin{array}{lll}\text { Carnivorous } & \text { Plants } & \text { Newsletter }\end{array}$ https://cpn.carnivorousplants.org/articles/CPNv41n3p105_108.pdf

Chua LSL, Saw LG (2001). A reassessment of the flora of Gunung Ulu Kali, Genting Highland, Malaysia - preliminary findings and trends. Malayan Nature Journal 55(1-2):65-76.

Ellison AM (2006). Nutrient limitation and stoichiometry of carnivorous plants. Plant Biology 8(6):740-747. https://doi.org/10.1055/s-2006-923956

Ghazalli MN, Tamizi AA, Nikong D, Besi EE, Mat Esa MI, Mohd Nordin AR, ... Shakri MA (2020). Nepenthes latiffiana and $N$. domei (Nepenthaceae), two new species of pitcher plants from Terengganu, Peninsular Malaysia. Webbia 75(1):5-28. https://doi.org/10.36253/jopt-7950

Mansur M, Brearley FQ, Rode-Margono EJ, Esseen PJ, Ma'arif Tarigan MR (in revision). Ecology of Nepenthes clipeata on Gunung Kelam, Indonesian Borneo. Plant Ecology and Diversity.

McPherson S, Robinson A (2012). Field guide to the pitcher plants of Peninsular Malaysia and Indochina. Redfern Natural History Publications, Poole, Dorset, UK.

Ng YJ, Go R, Nulit R, Khor HE, Tan MC, Nordin FA, Nuruddin AA, Lee NS (2012). Orchids of cloud forest in Genting Highlands, Pahang, Malaysia. Sains Malaysiana 41(5):505-526. https://www.ukm.my/jsm/pdf_files/SM-PDF41-5-2012/01\%20Ng\%20Yong\%20Jin.pdf

Osunkoya OO, Daud SD, Di-Giusto B, Wimmer FL Holige TM (2007). Construction costs and physico-chemical properties of the assimilatory organs of Nepenthes species in northern Borneo. Annals of Botany 99(5):895-906. https://doi.org/10.1093/aob/mcm023

Piggot AG (1977). The ferns of Gunong Ulu Kali. Gardens' Bulletin Singapore 30:31-43. https://www.nparks.gov.sg/sbg/research/publications/gardens-bulletin-singapore/-/media/sbg/gardensbulletin/4-4-30-08-y1975-v30-gbs-pg-31.pdf

Pugnaire FI (2001). Variability of inorganic nutrient concentrations in leaves. New Phytologist 150(3):506-507. https://doi.org/10.1046/j.1469-8137.2001.00144-2.x

Rotkittikhun P, Kruatrachue M, Chaiyarat R, Ngernsansaruay C, Pokethitiyook P, Paijitprapaporn A, Baker AJM (2006). Uptake and accumulation of lead by plants from the Bo Ngam lead mine area in Thailand. Environmental Pollution 144(2):681-688. https://doi.org/10.1016/j.envpol.2005.12.039

Saw LG (2010). Vegetation of Penisular Malaysia. In: Kiew R, Chung RCK, Saw LG, Soepadmo E, Boyce PC (Eds). Flora of Peninsular Malaysia. Series II: Seed Plants, Volume 1, Malayan Forest Records No. 49. Forest Research Institute Malaysia, Kepong, Malaysia pp 21-45 - 293-300.

Shivas RG (1983). Nepenthes of Gunung Ula Kali. Carnivorous Plants Newsletter 12(3):65-67. https://cpn.carnivorousplants.org/articles/CPNv12n3p65_67.pdf

Stone BC (1981). The summit flora of Gunung Ulu Kali (Pahang, Malaysia). Federation Museums Journal 26(1):1-157.

Tamizi AA, Ghazalli MN, Nikong D, Besi EE, Mat Esa MI, Mohd Nordin AR, ... Shakri MA (2020). Nepenthes malayensis (Nepenthaceae), a new species of carnivorous pitcher plant from Peninsular Malaysia. Kew Bulletin 75(4):63. https://doi.org/10.1007/s12225-020-09918-z

Tanner EVJ, Vitousek PM, Cuevas E (1998). Experimental investigation of nutrient limitation of forest growth on wet tropical mountains. $\quad$ Ecology $79(1): 10-22 . \quad h t t p s: / /$ doi.org/10.1890/00129658(1998)079[0010:EIONLO]2.0.CO;2 
The Star (2016). At the height of biodiversity. Retrieved 2021 May 11 from https://www.thestar.com.my/metro/focus/2016/07/12/at-the-height-of-biodiversity-130-millionyearoldforest-in-genting-highlands-among-highlights-of-int/

Thorogood CJ, Bauer U, Hiscock SJ (2018). Convergent and divergent evolution in carnivorous pitcher plant traps. New Phytologist 217(3):1035-1041. https://doi.org/10.1111/nph.14879

van der Ent A, Sumail S, Clarke CM (2015). Habitat differentiation of obligate ultramafic Nepenthes endemic to Mount Kinabalu and Mount Tambuyukon (Sabah, Malaysia). Plant Ecology 216(6):789-807. https://doi.org/10.1007/s11258-015-0468-6

Whitmore TC, Burnham CP (1969). The altitudinal sequence of forests and soils on granite near Kuala Lumpur. Malayan Nature Journal 22(3-4):99-118.
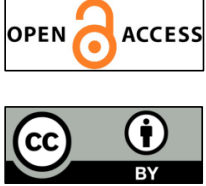

The journal offers free, immediate, and unrestricted access to peer-reviewed research and scholarly work. Users are allowed to read, download, copy, distribute, print, search, or link to the full texts of the articles, or use them for any other lawful purpose, without asking prior permission from the publisher or the author.

License - Articles published in Notulae Scientia Biologicae are Open-Access, distributed under the terms and conditions of the Creative Commons Attribution (CC BY 4.0) License.

(C) Articles by the authors; SHST, Cluj-Napoca, Romania. The journal allows the author(s) to hold the copyright/to retain publishing rights without restriction. 